\title{
An Econometric Analysis of Maize Farmer's Choice of Land Ownership Systems: Evidence Using Panel Data from Tanzania
}

\author{
Jovin A. Lasway \\ Research Assistant; Department of Strategic Research and Publications, \\ Economic and Social Research Foundation, Dar es Salaam, Tanzania \\ laswayjovinı3@gmail.com
}

Onesmo Selejio

Senior Lecturer; School of Economics, University of Dar es Salaam, Dar es Salaam, Tanzania oselejio@gmail.com

\begin{abstract}
This paper determines the socioeconomic and physical characteristics that influence maize farmer's choice of land ownership systems in Tanzania, i.e., owned, sharecropped, and rented title land. The paper uses the Tanzania National Panel Survey (TZNPS) data basing on 2,073 observations comprising of a sample size of 691 households in three consecutive waves 2008/2009, 2010/2011, and 2012/2013. Using a t-test for mean comparison, the paper found that there is a significant difference between male and female-headed households across socioeconomic and physical factors determining the choice of land ownership systems among maize smallholder farmers. Moreover, the paper findings revealed that 90 percent, 7 percent, and 3 percent of the sampled maize smallholder farmers chose to farm under-owned, shared, and rented title land system respectively. Furthermore, the econometric analysis which is grounded from the multinomial logit regression model showed that accessibility, farm size, quantity harvested, accessibility of extension services, gender, household size, and age are all pertinent in influencing the smallholder maize farmer's choice of land ownership. The paper recommends that these characteristics of the smallholder maize producers should be critically considered when formulating any land and agricultural policies to enhance proper decision making by smallholder farmers on the choice of land ownership system that may led to sustainable agricultural production, productivity, and food security in developing countries particularly in Tanzania.
\end{abstract}




\section{Keywords}

land ownership systems - multinomial logit model - smallholder maize farmers panel data - Tanzania

\section{Introduction}

About 44.8 percent of Tanzania's land is categorized as agricultural land at which agriculture accounts 24 percent of the Gross Domestic Product (GDP), 30 percent of the total exports, 65 percent of raw materials for the industrial sector, and 67 percent to employment in Tanzania (United Republic of Tanzania, 2016a). Most of the rural communities in Tanzania are lacking awareness of land use (United States Agency for International Development, 2017; Food and Agriculture Organization, 2018). During the Ujamaa ${ }^{1}$ period, the country adopted a land policy on communal land use whereby collective cultivation of land was highly encouraged to promote large scale collective farming. However, during 1986 there were changes that led to a reversal of this land policy and the customary land law was enacted to promote individual rights to own land which would promote investment and upsurges productivity (Collins et al., 2019). The current land laws of the Village Land Act (VLA) of 1999 and Land Act of 1999 have more improved the situation of land governance in the legal framework. These two land laws have established the basic three land categories: Village, General, and Reserved Land. Moreover, village land is controlled by a village council that is responsible for land management decisions including issuing the certificates of customary right of occupancy and administering the local registers of land rights. General land includes all unused and unoccupied village land and usually located in urban and periurban areas while reserved land includes land reserved for national parks, forestry, public game parks, and game reserves.

Food Agriculture Organization (2018) defines land ownership systems as legal means to transfer, manage, or make improvements, exclude others, and control the proceeds from the land. Furthermore, Sklenicka et al. (2019) and Melesse et al. (2020) highlight that farming land arrangements the farmers' land ownership systems are categorised into owned; rented, and share land

1 Swahili word for "family hood" was economic and social policy development implemented in Tanzania initiated by President J. K. Nyerere between 1964 and 1985. It was grounded on self-reliance at both individual and national levels. 
title systems. ${ }^{2}$ Land ownership system is a significant part of economic, social, and cultural structures that defines land property rights to be well allocated into societies (World Bank, 2014). Thus, land ownership systems determine and regulate who can use what resources, under what conditions, and at what period (Sipangule, 2017). In many developing countries like Tanzania, land ownership affects the management of natural resources which has accelerated to attract more attention in modern studies on how to promote sustainability of natural resources management (Mekasha et al., 2018; Ringo, 2018; Massoi, 2019). It has been observed that countries having limited land ownership systems are facing problems in accommodating vital changes in the agricultural and industrial sectors, at which the development and growth of such economies have deteriorated (Keovilignavong and Suhardiman, 2020). Thus, proper land ownership systems among farmers have emerged as a focal point in addressing agricultural production since most of the agricultural production in Africa is land motivated. However, agricultural production in Africa including Tanzania is highly associated with low productivity due to the limited nature of land ownership systems (United Republic of Tanzania, 2016a). Mekasha et al. (2018) documents that proper arranged land ownership systems influence agricultural productivity and production through effective land security and investment demand. For instance, a limited land ownership system hinders socioeconomic investment which has contributed to slow economic growth in most developing countries (Gebreeyosus et al., 2020). Therefore, a proper land ownership system among farmers in Tanzania is vital due to its role on contributing development particularly in rural areas (Kinuthia et al., 2019). It has been documented that farmers with proper land ownership systems tend to invest more in their lands leading to sustainable agricultural productivity (Sipangule, 2017). Hence, the proper choice of land ownership system motivates the farmers to undertake land-related farming investments which enhance productivity.

Due to the high demand for agricultural commodities such as maize as staple crop, farmers with limited farming land plots find any means to acquire plenty of farmland for maize cultivation (Pallotti and Tornimbeni, 2016; United

2 Farmer's owned title land system refer as a farmer own land for practicing his/her farming activities. Rented title land means that a farmer pays a fixed rent for the land he/she rents and, thus, bears the full marketing risk; although, the farmer also obtains all the proceeds growing out of his labour. Thus, this system of land ownership under farming activities requires a farmer to be economically sound. Share title land refers to a system of land ownership at which a landowner allows a farmer to use the land in return for a share of the crops being produced on a particular land. Thus, the gross output is divided between the landlord and a farmer. 
Republic of Tanzania, 2016a). However, the maize farmers' decisions on choosing a particular land ownership system are highly determined by their socioeconomic and physical characteristics. These characteristics have not been given much attention in most of the literature in developing countries particularly Tanzania whereas maize is a main staple food. Most of the literature on the maize production in Tanzania are focusing on the adoption of modern agricultural technologies, productivity, efficiency, and land tenure effect on soil degradation (de Brauwand Mueller, 2012; Kassie et al., 2013; Kassie et al., 2015; Selejio et al., 2018; Selejio and Lasway, 2019; Lasway et al., 2020, 2021). This paper attempts to bridge this gap by contributing to the knowledge on considering the socioeconomic and physical factors that affect the maize farmers' choice of systems of land ownership in Tanzania. Furthermore, the findings of this paper show that 9o percent, 7 percent, and 3 percent of the sampled maize smallholder farmers chose to farm under-owned, shared, and rented title land system respectively. Moreover, the main findings reveal that education, access to credit, and extension services are significant to influence maize farmer's choice of land ownership system to enhance food security. Hence, these factors could be very useful to policymakers particularly in formulating appropriate land policies towards promoting agricultural production and productivity in Tanzania. After this introduction the paper is organized as follows: Section two provides the background of the land ownership systems in Tanzania while section three presents a review on evidence of land ownership systems among farmers and its associated factors. Materials and methods are presented in section four while section five presents results and discussion. Lastly, section six provides a conclusion.

Background of the Land Ownership Systems in Tanzania

The historical background of the land ownership systems in Tanzania dates back to the pre-colonial administration of the then Tanganyika (Isinika and Mutabazi, 2010). The land ownership of pre-colonial administration was maintained under the chiefly system (Nnkya, 1999). This system was ignored by the British colonial administration in Tanganyika which introduced the Land Ordinance in 1923 (Tsikata, 2003). The land ordinance centralized the land ownership under the colonial governor who was responsible for granting occupancy rights particularly to colonial settlers. Shivji (1999a) argues that this land ordinance remains the basis for land ownership in Tanzania. During the post-independence, the country adopted several legal land frameworks which enhanced the land ownership systems. During the Ujamaa period, the country 
imposed several restrictions which limited the foreigners to own and occupy land whereby the land ownership was decentralized to the village governments (Shivji, 1999b).

In the 1990s, the country underwent significant land reforms such as the National Land Policy (1997), Land Act (1999) and the Village Land Act (1999). These reforms attempted to amend the historical injustices regarding the land ownership systems in terms of gender and administration (Wily, 2012). Moreover, these reforms noted that the land ownership is controlled by the President, individuals, villages, and organisations (United Republic of Tanzania, 1995, 1999a, b). ${ }^{3}$ However, the 1995 Land Policy reaffirms that all land in Tanzania is regarded as public land vested in the President as trustee on behalf of all citizens. Tsikata (2003) and Rwegasira (2012) document that despite of the formulation of these reforms, the situation has not improved on legal land framework and governance ownership systems particularly for agricultural smallholder farmers. In this regard, the revised National Land Policy (2016) was formulated which reflected the importance of agriculture and was anchored on the three land ownership systems i.e., owned, rented land and sharecropped land that smallholder farmers can dwell on (United Republic of Tanzania, 2016a). More importantly, National Bureau of Statistics (2017) projected that the agricultural production of the country would substantially increase by 3 percent per year if the proper farming choices of land ownership systems are made by smallholder farmers. Henceforth, the land ownership systems are vital because of the predominance of agriculture in the economy. In this aspect, the legal framework of land ownership in Tanzania is highly influenced by the historical development.

\section{3}

Evidence of Land Ownership Systems among Farmers and Its Associated Factors

Empirically, the literature on land ownership systems among farmers is quite rich. The literature indicate that there is a wide variation of factors influencing farmers on choosing a particular land ownership system. A vast number of studies show that farmers' decisions on choosing land ownership systems do not consider agricultural productivity (Ghatak and Roy, 2007; Twyman et al., 2015; Huang et al., 2020). For example, Donkor and Owusu (2014) apply the Multinomial probit model to study determinants of rice farmer's choice of

3 The mentioned entities are the only ones who can secure legal rights of land occupancy and use in the country. 
land ownership systems in the upper east region of Ghana. The study used cross-sectional data and revealed that 76 percent, 21 percent, and 3 percent of the rice farmers were landowners, rented titles, and shared titles respectively. Furthermore, the study found that age, marital status, extension contact, household head, and credit access influenced the rice farmer's choice of land ownership system to increase agricultural production.

Panichvejsunti et al. (2018) using cross-sectional data of 16o observations investigated smallholder farmers' crop combinations under different land tenure systems in Thailand. The study employed a multi-stage sampling procedure revealed that farmers' land ownership system is being influenced by farm characteristics. For instance, farmers with proper land ownership systems are being influenced to cultivate more crop types for household consumption and additional income. Furthermore, farmers with land rights restrictions (i.e., shared land and rent land) are only influenced to cultivate one crop type for major means of income. According to Antwi-Agyei et al. (2015) documents that farmers' land-use decisions depend on various factors not only farm characteristics but also traditional practices, skills, profit, cost, and knowledge. The study further finds that the education level of a farmer is a significant factor in influencing a farmer to choose a particular land ownership arrangement. The study points out that farmers with high education levels have higher likelihood to own land than renting. The results concur with the findings in Guizhou province in China where farmers with higher education level are less likely to rent farmland since are more risk-averse (Mullan et al., 2011).

Accessibility of extension services from the Government and other development agricultural organizations are crucial determinants of land ownership arrangements from the farmers (Mwesigye et al., 2020). The study used cross-sectional data on investigating the status of farmers' land rights specifically on women and their implications for agricultural productivity in Uganda. The study further indicates that farmers with ownership of land rights have a higher likelihood to enhance agricultural productivity than farmers with rented lands. The study agrees with Place and Otsuka (2002) and Lawry et al. (2017) since farmers with ownership of land rights have more access to extension services which contributes to increasing agricultural productivity. Unlike farmers with rented lands.

Asaaga and Hirons (2019) employed a mixture of qualitative methods and a household survey among 380 farmers in Southcentral and Western of Ghana, to investigate the mechanisms of land access, arrangements, control focusing on its determinants. The study further revealed that accessibility of credit and farmers' membership associations are significant in influencing farmers to rent and own land. The study showed that farmers with credit and membership association access have the advantage to adopt Improved Agricultural 
Technologies (IATs) which enhances agricultural productivity. This concurs with several studies in Tanzania expound that maize farmers with credit accessibility and members of the farmers associations have a greater advantage to adopt IATs and increase their productivity (Kassie et al., 2015; Selejio and Lasway, 2019; Lasway et al., 2020).

The low agricultural productivity in Sub-Saharan Africa (SSA) implies that food security is at risk. As has been noted, agricultural production in Africa is greatly linked with low productivity. One of the major constraints to higher crop productivity among smallholder farmers in SSA is due to the uncertain nature of land ownership systems (Sanchez, 2015; Lasway et al., 2020). For instance, currently, the maize yield productivity in Tanzania is $1.45 \mathrm{t} / \mathrm{ha}$ whereas with good management the yield is estimated to $4.0 \mathrm{t} / \mathrm{ha}$ (United Republic of Tanzania, 2012, 2016b). However, maize yield must be increased to $6.8 \mathrm{t} / \mathrm{ha}$ in order to meet the estimated demand in 2050 (United Republic of Tanzania, 2016b). Thus, a policy that advocates and guide farmers to choose proper land ownership system enhancing efficiency in agricultural productivity is important for sustainable food security.

Furthermore, the above empirical literature review shows that many studies used cross-sectional data which are more likely to suffer from an endogeneity problem which makes it difficult to control for unobserved heterogeneity. For this reason, this paper uses the advantage of employing panel data in the analysis for unbiased and more enlightening results. Therefore, the findings on modeling maize farmer's choice of land ownership systems could bring significant information to policymakers to understand the big picture of linkage between land ownership systems, agricultural production, and productivity in Tanzania.

\section{Materials and Methods}

\subsection{Analytical Framework}

This paper is grounded on the theory of utility maximization using a random utility model based on McFadden (1984) and Wooldridge (2019). Specifically, this paper explores the smallholder maize farmers' decisions on land ownership systems in Tanzania. The land ownership system model expounds the decision made by a maize smallholder farmer $i=1,2,3 \ldots, I$ of all alternative $j$ in the set $\left(C_{i}=1, \ldots, j\right.$ which yields the level of the highest utility. Thus, the choice set is acceptable to vary across the maize smallholder farmers to count their own particular available land ownership system. The systems of land ownership choices of maize smallholder farmers are 1, 2, and 3 which denote owned land, rented land and sharecropped land respectively. The base category 
(option o) is owned land at which the utilities of other systems of land tenure which are rented and sharecropped are compared to the base category. Furthermore, the maize smallholder farmer decision is grounded on the differences between a derived utility from the other systems of land ownership and the base category which is owned land.

The utility $U_{i j}$ derived by the $i$ th individual from the $j$ th alternative can be written as:

$$
U_{i j}=V_{i j}+\varepsilon_{i j}=\beta_{j}^{i} X_{i}+\varepsilon_{i j}
$$

where $V_{i j}$ represents average utility, $\varepsilon_{i j}$ is the random part, $X_{i}$ means matrix of the characteristics of maize smallholder farmer $i$, and $\beta_{j}$ is the vector's parameter for each alternative. Following the development of random utility theory, the probability, $P_{i j}$ that maize smallholder farmer $i$ selects alternative $j$ equals the probability that $U_{i j}$ is larger than the utilities $U_{i k}$ of all other alternatives in the smallholder maize farmer's choice set, $\mathrm{C}$.

This is denoted as:

$$
\begin{array}{lll}
P_{i j}=P\left(U_{i j} \geq U_{i j}\right. & \forall k \in C & k \neq j), \\
P_{i j}=P\left(V_{i j}+\varepsilon_{i j} \geq V_{i k}+\varepsilon_{i j}\right. & \forall k \in C & k \neq j),
\end{array}
$$

assuming that, random components of the utility $\left(\varepsilon_{i j}\right)$ are identically and independently distributed, the expression of the probability of an individual $i$ choosing an alternative $j$ as given by (Wooldridge, 2019).

\subsection{The Functional Form of the Estimated Equation}

The model in this paper is anchored on the methodology to show the advantageous application of multinomial regression approaches to maize smallholder farmers' decisions on land ownership arrangements in Tanzania. In choosing a functional form for the estimated equation, there are two alternatives. One alternative is the Multinomial Logit Model (MNLM), and the Nested Multinomial Logit Model (NMLM). The former model is well known to suffer from the problem of Independence from Irrelevant Alternatives (IIA). Thus, this would seem to make NMLM more attractive since it works well in situations where alternatives are quite dissimilar. McFadden et al. (2007); Athey and Imbens (2007), and Wooldridge (2019) document that there is no well-defined testing structure for discriminating among tree structures. Besides, McFadden (1984) points out that "empirical experience is that the MNL is relatively robust, as measured by goodness of fit or prediction accuracy, in many cases where the 
IIA property is theoretically implausible." Thus, non-nested MNLM is also easier to deal with computationally. For this empirical evidence, this paper uses the model which is estimated based on a standard MNLM given as:

$$
\operatorname{Pr}(y=j)=\frac{\ell^{x \beta^{(j)}}}{\ell^{x \beta^{(1)}}+I \ell^{x \beta^{(j)}}+I+\ell^{x \beta^{(J)}}},
$$

whereas, in the context of this paper, the MNLM analysis determines the likelihood of a maize smallholder farmer selecting one of the different systems of land ownership (owned land, rented land, and sharecropped land), given his/ her socioeconomic, institutional and physical characteristics. Therefore, the empirical MNLM regression model can be indicated in equation (5):

$$
\begin{aligned}
& Y_{i j}=\beta_{0}+\beta_{1} \text { Gender }_{+}+\beta_{2} \text { Soil_Quality }_{i}+\beta_{3} \text { Age }_{i}+\beta_{4} \text { Acc_Extension }_{i}+ \\
& \beta_{5} \text { Acc_Credit }_{i}+\beta_{6} \text { Household_Size }_{i}+\beta_{7} \text { Education }_{i}+\beta_{8} \text { Farm_Size }_{i}+ \\
& B_{9} \text { Quantity }_{\text {Harvested }}+E_{i j},
\end{aligned}
$$

where $Y_{i j}(j=1,2$, and 3$)$ represent the maize farmer's choices of land ownership systems i.e., 1 - owned land which is a base category (option o), 2 - rented title, and 3 - sharecropped title land. The intersect is signified by $\beta_{0}$, the coefficients of the independent variables are represented by $\beta_{1}-\beta_{9}$. The disturbance error term is signified by $\varepsilon_{i j}$.

Gender $_{i}$ represents a gender variable, 1 if a maize farmer was a male and o

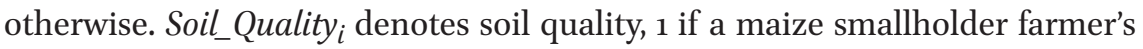
plot farm had a good soil quality and o otherwise. Age $e_{i}$ symbolizes the age of the head of household (maize smallholder farmer) and it's measured in sev-

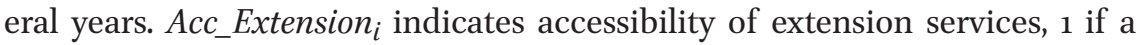
maize smallholder farmer had access to extension services and o otherwise. Acc_Credit ${ }_{i}$ implies accessibility of credit services, 1 if a maize smallholder farmer had access to credit services and o otherwise. Household_Size $e_{i}$ entails household size involving household members within the family, it's a continuous variable which is a proxy of only labour availability within the household.

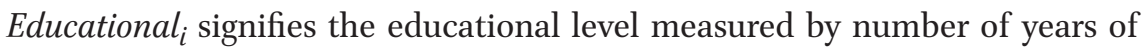
schooling. Farm_Size $e_{i}$ represents the cultivated size of the firm by the smallholder maize farmer (acres). Quantity_Harvested denotes quantity harvested by a maize smallholder farmer per annum measured in Kilograms (Kg).

Importantly, this papers attempts to minimize the problem of Yule-Simpson Paradox by developing a model that includes all the necessary control variables that have significant effect on the dependent variable as suggested by Bellemare (2016). 


\subsection{Data Source and Sampling Procedure}

The analysis uses the Tanzania National Panel Survey (TZNPS) data that was collected by the National Bureau of Statistics (NBS) with collaboration from the World Bank as a funder. The households used in this paper were interviewed in waves; first-wave 2008/2009, second wave 2010/2011, and thirdwave $2012 / 2013 .{ }^{4}$ The survey was designed to represent targeted households at urban/rural levels and all major agro-ecological zones.

Initially, the dataset had 1,104, 1,162, and 1,278 households for the first wave $2008 / 2009$, second wave 2010/2011, and third-wave 2012/2013 respectively which included only maize smallholder farmers. The analysis of this paper considers only households who have been engaging in maize farming at all three waves. Therefore, to have a strongly balanced panel dataset of maize farming households, data cleaning, merging, and appending were conducted to track only maize smallholder farmers under different land ownership systems specifically on owned, rent, and cropped shared land within a three waves period of Tanzania National Panel Survey.

Subsequently, the analysis of a strongly balanced panel dataset was based on 2,073 observations comprising of 691 samples of maize smallholder farmers in three waves 2008/2009, 2010/2011, and 2012/2013. The sample of panel data in this paper comprises of households from Tanzania Mainland only. Households from Zanzibar were dropped during the sampling procedure since the maize crop is cultivated at a very small proportion. The panel data contains information on harvest at household level; and household characteristics such as individual interviewees' age, gender, education, household size, farm size, soil quality, accessibility of credit, and extension services. This paper used the panel rich information to analyze the linkages of interest as raised in the motivation of the study.

\section{5}

\section{Results and Discussion}

\subsection{Descriptive Results}

The descriptive statistics are presented in Table 1. The descriptive statistics indicate that the average age of the household head was 49 years with a minimum and maximum of 19 and 92 years of age respectively. About 76 percent of

4 The intention of using three waves instead of four waves is that the fourth wave (2014-2015) which is the latest is based on data from new households only which is impossible for balanced panel data analysis to be conducted when including the fourth wave and may lead to high attrition if merged to the previous waves. 
the households were headed by the male while 24 percent by female, with an average household size of 5.5 persons with a minimum and maximum of 1 and 35 household members respectively. The descriptive results show that the average education of the sampled household heads is 7.2 years in school, with 0 and 17 as the minimum and maximum number of schooling years respectively; implying that the literacy rate of the maize smallholder farmers in the study area is low. This descriptive finding is supported by Bellemare (2012) revealed that most of the farming households in many developing countries including Madagascar and Tanzania have minimum schooling years. The study observed that 21 percent and 49 percent of the sampled household maize smallholder farmers had access to credit and extension services respectively. This implies that most of the maize smallholder farmers had no accessibility of credit and extension services, similar results have been also reported by Ndiritu and Ruhinduka (2019). The descriptive results depict that only 13 percent of the maize smallholder farmers cultivated their staple crop on plots with good soil quality having an average of 5.1 acres of the farm size per household with minimum and maximum of 0.005 and 42 acres respectively. Furthermore, the descriptive results show that the maize quantity harvested by smallholder farmers ranged from 1 to 40,000 kgs with average units of 443 during the surveyed panel years.

TABLE 1 Descriptive statistics of the socioeconomic and physical characteristics of the maize smallholder farmers

\begin{tabular}{lccrcr}
\hline Variable & Observation & Mean & Std.dev. & Min & Max \\
\hline Age & 2073 & 49.17 & 15.269 & 19 & 92 \\
Household Size & 2073 & 5.54 & 2.835 & 1 & 35 \\
Education & 1594 & 7.12 & 2.867 & 0 & 17 \\
Gender & 2073 & .764 & .425 & 0 & 1 \\
Acc_Extension & 2073 & .492 & .5 & 0 & 1 \\
Acc_Credit & 2073 & .215 & .411 & 0 & 1 \\
Farm_Size & 2073 & 5.12 & 5.185 & .005 & 42 \\
Soil_Quality & 2073 & .133 & .339 & 0 & 1 \\
Quantity_harvested & 2012 & 443.1 & 1097.723 & 1 & 40000 \\
\hline
\end{tabular}

SOURCE: AUTHORS' COMPUTATION FROM THE TANZANIA NATIONAL PANEL SURVEY DATASET USING STATA 14.2 SOFTWARE 


\subsection{The Choice of Land Ownership Systems Opted by the Maize Smallholder Farmers}

The paper identifies three (3) significant land ownership systems operated by maize smallholder farmers in Tanzania during the surveyed years which include owned, rented, and sharecropping title land. Figure 1 indicates that most of the maize smallholder farmers opted to farm on their owned farmlands which accounted 89.18 percent, 91.34 percent, and 90.04 in 2008, 2010, and 2012 respectively. The farmland owners acquired their plots through gifts, inheritance, family, and marriage. Furthermore, the descriptive results reveal that a small percentage of maize smallholder farmers opted to rent the farmland in 2008 ( 3.75 percent), 2010 ( 2.74 percent), and 2012 (2.31 percent). Likewise the maize smallholder farmers engaged in sharecropping arrangement was relatively small in 2008 ( 7.07 percent), 2010 ( 5.92 percent), and 2012 (7.65 percent). This implies that most of the smallholder farmers opted to farm on their farmlands and the major reason is that they were risk-averse to rent or practicing sharecropping land ownership systems. This descriptive finding is supported by the United Republic of Tanzania (2016b) which revealed that 86 percent of the smallholder farmers in Tanzania tend to farm only on their farmlands and are risk-averse to diverge on other land ownership systems. Also, farming on owned farmland is a huge prestige in African culture which is one of the reasons that influenced most of the maize smallholder farmers to farm on their farmlands during the surveyed years (United Republic of Tanzania, 2016b).

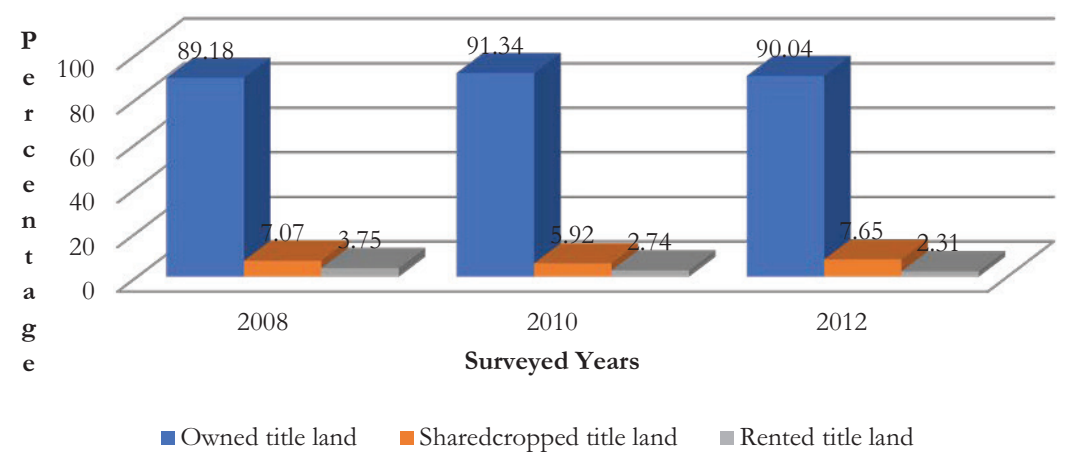

FIGURE 1 The choice rates of land ownership systems among maize farming households during the agricultural panel surveyed years SOURCE: AUTHORS' COMPUTATION FROM THE TANZANIA NATIONAL PANEL SURVEY DATASET 


\subsection{Socio-Economic, Institutional and Physical Characteristics Determining Choice of Land Ownership by Gender}

The results in Table 2 indicate that there is a significant difference between male and female-headed households across different socio-economic and physical factors determining the choice of land ownership systems among maize smallholder farmers. Meaning that, the male-headed household significantly differs from a female-headed household in several aspects except a few such as accessibility of extension services and credit. The influence of households' characteristics such as age, household size, education, quantity harvested, farm size, and soil quality in determining the choice of land ownership systems among maize smallholder farmers significantly differ between the male and female-headed households. Most of the literature, such as Donkor and Owusu (2014), Lawry et al. (2017), Panichvejsunti et al. (2018), and Asaaga and Hirons (2019), focusses mostly on the farmer's gender and how it impacts his/her choice on land ownership systems but this paper has shown that there is a significant difference in determining decision on choosing certain land ownership systems among maize smallholder farmers between male and female-headed household.

TABLE 2 Differences in socio-economic, institutional and physical characteristics determining choice of land ownership by Gender T-test

Variables

Mean

Mean diff

Female Male

$\begin{array}{lrrr}\text { Age } & 55.470 & 47.222 & 8.248^{* * *} \\ \text { Household_Size } & 4.304 & 5.919 & -1.614^{* * *} \\ \text { Education } & 15.831 & 16.527 & -0.695^{* * *} \\ \text { Quantity_harvested } & 4.932 & 5.437 & -0.505^{* * *} \\ \text { Acc_Extension } & 0.462 & 0.501 & -0.039 \\ \text { Acc_Credit } & 0.208 & 0.216 & -0.008 \\ \text { Farm_Size } & 3.165 & 5.728 & -2.563^{* * *} \\ \text { Soil_Quality } & 0.102 & 0.142 & -0.039^{* *}\end{array}$

Legends: *,**, *** represents a significant difference at 1 percent, 5 percent, and 10 percent respectively.

SOURCE: AUTHORS' COMPUTATION FROM THE TANZANIA NATIONAL PANEL SURVEY

DATASET USING STATA 14.2 SOFTWARE 


\subsection{Econometric Analysis}

5.4.1 Multinomial Logit Regression Results

This paper uses a multinomial logit regression model to determine socioeconomic and physical characteristics that influence maize smallholder farmer's decisions on choosing certain land ownership systems in Tanzania during the panel surveyed years. Table 3 shows the relative direction between the outcome variable and its independent variables.

TABLE 3 Multinomial logit regression results

Farmer's choice of land Coef.

St. err

T-value P-value

Sig. ownership system

Owned title land (Base outcome)

Sharecropped title land

$\begin{array}{lrrrrr}\text { Age } & -0.013 & 0.009 & -1.55 & 0.120 & \\ \text { Household size } & -0.058 & 0.047 & -1.24 & 0.216 & \\ \text { Education } & 0.114 & 0.032 & 3.62 & 0.000 & * * * \\ \text { Gender } & -0.240 & 0.264 & -0.91 & 0.363 & \\ \text { Extension services } & 0.366 & 0.210 & 1.74 & 0.082 & * \\ \text { Credit services } & -0.039 & 0.244 & -0.16 & 0.872 & \\ \text { Farm size } & -0.074 & 0.031 & -2.37 & 0.018 & * * \\ \text { Soil quality } & 0.101 & 0.288 & 0.35 & 0.727 & \\ \text { Quantity Harvested } & 0.104 & 0.090 & 1.16 & 0.246 & * * * \\ \text { cons } & -3.840 & 0.884 & -4.42 & 0.000 & * * * \\ \text { Rented title land } & & & & & \\ \text { Age } & -0.042 & 0.016 & -2.61 & 0.009 & * * * \\ \text { Household size } & 0.104 & 0.061 & 1.71 & 0.088 & * \\ \text { Education } & 0.075 & 0.050 & 1.51 & 0.130 & \\ \text { Gender } & 1.053 & 0.623 & 1.69 & 0.091 & * \\ \text { Extension services } & -0.201 & 0.321 & -0.63 & 0.530 & \\ \text { Credit services } & 0.934 & 0.330 & 2.83 & 0.005 & * * * \\ \text { Farm size } & -0.265 & 0.073 & -3.61 & 0.000 & * * * \\ \text { Soil quality } & -0.412 & 0.511 & -0.81 & 0.421 & \\ \text { Quantity Harvested } & 0.340 & 0.146 & 2.33 & 0.020 & * * \\ \text { cons } & -5.532 & 1.485 & -3.73 & 0.000 & * * *\end{array}$


TABLE 3 Multinomial logit regression results (cont.)

\begin{tabular}{|c|c|c|c|}
\hline $\begin{array}{l}\text { Farmer's choice of land } \\
\text { ownership system }\end{array}$ & Coef. & T-value & P-value \\
\hline Mean dependent var & 1.124 & SD dependent var & 0.407 \\
\hline Number of obs & 1546.000 & Chi-square & 89.253 \\
\hline Prob $>$ chi2 & 0.000 & Akaike crit. (AIC) & 1101.509 \\
\hline Bayesian crit. (BIC) & 1208.377 & Pseudo r-squared & 0.078 \\
\hline
\end{tabular}

Legends: ${ }^{*} p<0.1,{ }^{* *} p<0.05,{ }^{* * *} p<0.01$.

SOURCE: AUTHORS' COMPUTATION FROM THE TANZANIA NATIONAL PANEL SURVEY

DATASET USING STATA 14.2 SOFTWARE

Furthermore, to determine the relative effectiveness of a unit change in the value of an independent variable on the choice of land ownership system probability, the marginal effects after the multinomial logistic regression are computed. Therefore, the marginal effects results are presented in Table 4. Owned title land was outcome variable for the multinomial logit analysis. The results show that among of the fitted variables in the models, only three (3) variables are statistically significant influencing the probability that a maize smallholder farmer would choose to farm under sharecropped land ownership system. These include farmer's education level, accessibility of extension services, and farm size. Again, six (6) variables significantly influence the probability that a maize smallholder farmer would rent farmland. These include age, household size, gender, credit services, farm size, and quantity harvested.

The age of the maize smallholder farmer is statistically significant at 5 percent negatively influencing the decision to opt farming on the rented land. The findings entail that a year increase in maize smallholder farmer's age decreases the likelihood to farm on rented land by 0.0005 units. This implies that older farmers are risk-averse on renting farmlands compared to younger ones. The findings concur with several studies such as Donkor and Owusu (2014) and Keovilignavong and Suhardiman (2020). However, the paper findings disagree with Lawry (2017) who documents that older farmers have a higher likelihood to farm on rented lands due to the accumulation of income through their entire farming career. The reason for disagreement with Lawry (2017) is that farmers might accumulate huge income but once he/she does not have proper marketing and financial knowledge through formal education services might end up being risk-averse. 
TABLE 4 Marginal effects after multinomial logit model regression results

\begin{tabular}{|c|c|c|c|c|c|c|}
\hline \multirow{3}{*}{$\begin{array}{l}\text { Explanatory } \\
\text { variables }\end{array}$} & \multicolumn{6}{|c|}{ Maize farmers' land ownership systems (outcome variable) } \\
\hline & \multicolumn{3}{|c|}{ Sharecropped title land } & \multicolumn{3}{|c|}{ Rented title land } \\
\hline & $\begin{array}{l}\text { Marginal } \\
\text { effect }\end{array}$ & Std. err & P-value & $\begin{array}{l}\text { Marginal } \\
\text { effect }\end{array}$ & Std. err & P-value \\
\hline Age & -0.001 & 0.000 & 0.132 & -.00049 & .0002 & 0.012 \\
\hline Household size & -0.003 & 0.003 & 0.202 & .00131 & .0008 & 0.082 \\
\hline Education & 0.006 & 0.002 & 0.000 & .00084 & .0006 & 0.189 \\
\hline Gender* & -0.015 & 0.017 & 0.376 & .00981 & .0045 & 0.030 \\
\hline $\begin{array}{l}\text { Extension } \\
\text { services* }\end{array}$ & 0.020 & 0.012 & 0.079 & -.00273 & .0039 & 0.493 \\
\hline Credit services* & -0.003 & 0.013 & 0.819 & .01484 & .0069 & 0.030 \\
\hline Farm size & -0.004 & 0.002 & 0.018 & -.00319 & .0008 & 0.000 \\
\hline Soil quality* & 0.006 & 0.017 & 0.723 & -.00446 & .0048 & 0.355 \\
\hline Quantity & 0.005 & 0.005 & 0.264 & .00408 & .0018 & 0.027 \\
\hline
\end{tabular}

Legend: * $\mathrm{dy} / \mathrm{dx}$ is for a discrete change of dummy variable from o to 1.

SOURCE: AUTHORS' COMPUTATION FROM THE TANZANIA NATIONAL PANEL SURVEY

DATASET USING STATA 14.2 SOFTWARE

The household size is positive statistically significant related to the maize smallholder farmer's decision on choosing to farm on rented land systems at 10 percent. The findings indicate that household size increases the propensity of maize smallholder farmers to farm on rented title land by o.0o1 units. This finding is supported by Mullan et al. (2011) and Massoi (2019) since households which are having many active members engaging in farming activities have a higher probability to practice farming on rented title land due to their economic stability in terms of labour and income status compared to households with fewer active members. The owned farm land also may not be sufficient to produce food and income to meet the requirements for members of large household and thus they rent the farming land to supplement the owned one.

The education level is positive on influencing maize smallholder farmer's decision to choose farming on the sharecropped land system and is statistically significant at 1 percent level. The findings entail that a year increase of education level of maize smallholder farmer increases the likelihood of 
choosing to farm on the sharecropped land system by 0.006 units. Therefore, maize smallholder farmer with higher education level has a higher propensity to farm on the sharecropped land system compared with the farmers having low education levels. Moreover, these empirical results agree with Pauw and Thurlow (2011), Twyman et al. (2015), and Gebreeyosus et al. (2020) with a reason that most educated farmers choose to practice farming on less costly land systems especially sharecropped which enables him/her to increase agricultural production.

The gender of a smallholder maize farmer is statistically significant in influencing farmer's decision to opt for which land ownership system to practice farming at 5 percent level. The empirical findings show that female smallholder farmers are likely to opt rented land system to practice farming activities by 0.01 units than male smallholder farmers. This finding concurs with Antwi-Agyei et al. (2015) and Melesse and Awel (2020) who argue that that female are more engaging in farming activities than male farmers and have less access to land in developing countries particularly in Africa which makes them have the higher likelihood to rent the farming land. However, Melesse and Awel (2020) documents further, most of the female farmers are renting farmlands but are being monitored and controlled by their husbands (male farmers). This occurs due to a cultural reason since most of the African cultures hinders female to rent land either for practicing farming or other related activities.

The findings show that accessibility of extension services ${ }^{5}$ is statistically significant at 1 percent level on influencing maize smallholder farmer's decision on choosing certain land ownership for farming. The findings entail that maize smallholder farmers who had received extension services had a higher likelihood to farm on rented land by 0.020 units. This finding is supported by Panichvejsunti et al. (2018) and Mekasha et al. (2018) who find that farmers who received extension services from the Government and other related organisations are having a higher propensity to farm on rented land since are having more agricultural and land potential knowledge compared to farmers who have no accessibility of extension services.

The variable of accessibility of credit services is statistically significant in influencing maize smallholder farmer's decisions on choosing certain land ownership systems at a 5 percent level. The findings depict that maize smallholder farmers who had access to credit services during the agricultural panel surveyed years, their likelihood to adopt rented farm plots for their farming activities increased by 0.015 units. This finding agrees with Ghatak and Roy (2007) and Collins et al. (2019), who found that there is a high probability

5 This paper covers only extension services provided by the Government extension agents. 
for farmers who receive credits to rent farm plots because of their economic power (income factor) compared to farmers who had no access to credits.

Farm size used by maize smallholder farmers during the agricultural panel surveyed years was found to negatively influence farmer's decision on choosing sharecropped and rented land systems for practice farming activities. The estimated coefficient of farm size is statistically significant at the 5 percent level with the sharecropped land ownership system and 1 percent level with the rented land ownership system. Thus, this entails that when a household head owns a larger farm size the propensity to practice sharecropping and renting land plots decreases by 0.004 and 0.003 units respectively. These findings agree with Sklenicka et al. (2019) and Melesse and Awel (2020) with a reason that due to African culture encompassing prestige when owning large farmland, thus due to this most smallholder farmer from remote areas in Africa do not have a tendency to rent or sharecropping the farmland.

The findings show that quantity harvested is statistically significant influencing maize farmers to opt for certain land ownership systems at a 5 percent level. The findings depict that an increase of one unit of quantity of harvest increases the likelihood of smallholder farmer to farm under rented ownership system by o.0041 units. Twyman et al. (2015), Asaaga and Hirons (2019), and Huang et al. (2020) support the paper's findings with a reason that the higher yield from the rented farm motivates a farmer to continue renting the plot because he/she economic gains from the farm. Correspondingly, the farmer has the stable income to accommodate other agricultural technologies (herbicides, irrigation, pesticides, improved seeds, and fertilisers, etc.) in the farm that would increase productivity and production.

Figure 2 reveals that the likelihood predictive mean effect of the decision of maize smallholder farmers to practice farming under-owned title land is increasing by 0.90 units and the 95 percent confidence interval of the effect is 0.89 to 0.91 units. The likelihood predictive mean effect of the decision of maize smallholder farmers to practice farming under sharecropped title land is increasing by 0.07 units and the 95 percent confidence interval of the effect is 0.05 to 0.08 units. Moreover, a decision of maize smallholder farmer's likelihood predictive mean effect to practice farming under rented title land is increasing by 0.03 units and the 95 percent confidence interval of the effect is 0.02 to 0.04 units. Thus, these empirical findings indicate that decisions of maize smallholder farmers are having a positive influence on choosing to practice farming under-owned, sharecropped, and rented title land but at different levels of predictive means during the three agricultural panels surveyed years. 


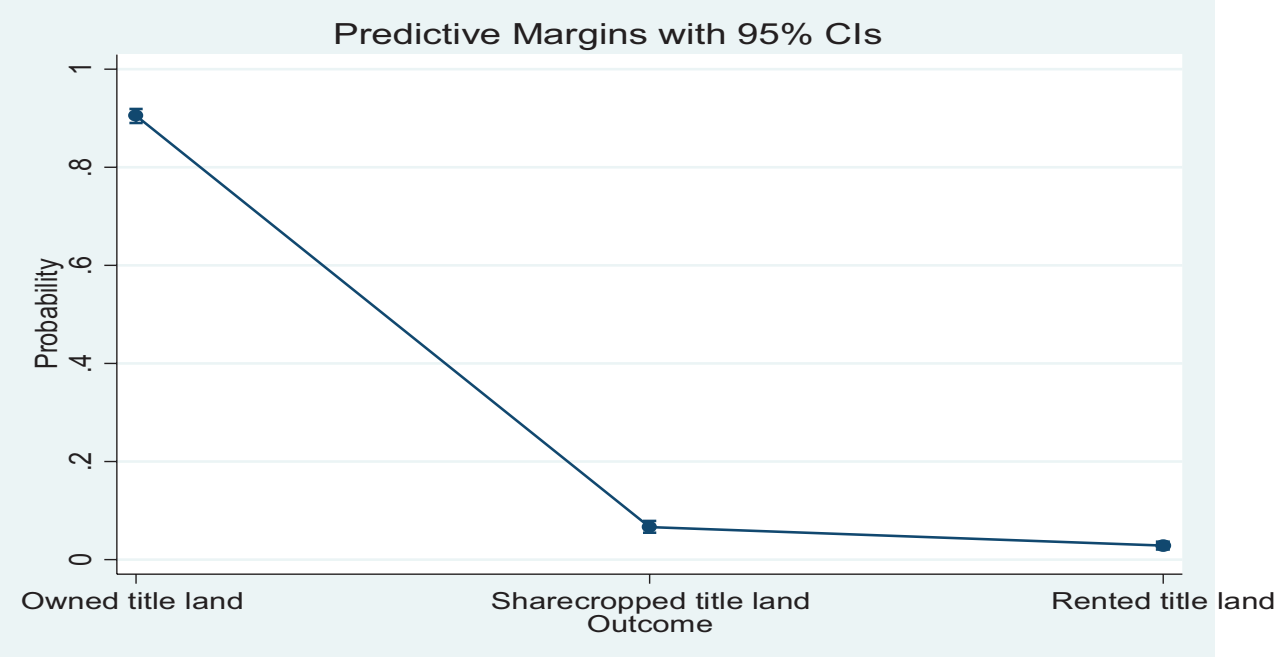

FIGURE 2 The results of the predictive margins on land ownership systems among maize farming households during the agricultural panel surveyed years SOURCE: AUTHORS' COMPUTATION FROM THE TANZANIA NATIONAL PANEL SURVEY DATASET USING STATA 14.2 SOFTWARE

\section{$6 \quad$ Conclusion}

This paper used the Tanzania Panel Data Survey basing on 2,073 observations comprising of 691 households' sample in three consecutive waves 2008/2009, 2010/2011, and 2012/2013. The paper modeled socioeconomic and physical characteristics that influence maize farmer's choice of land ownership system in Tanzania i.e., owned, sharecropped, and rented title land. The paper findings revealed that 90 percent, 7 percent, and 3 percent of the sampled maize smallholder farmers chose to farm under-owned, shared, and rented title land system respectively. Furthermore, the econometric analysis using the multinomial logit regression model entailed that farmer's decision was influenced by several characteristics such as education, credit accessibility, farm size, quantity harvested, accessibility of extension services, gender, household size, and age. Specifically, findings indicated that factors such as education, access to extension services, and farm size significantly influence the decision of maize smallholder farmers on choosing to farm under the sharecropped land system. Moreover, age, household size, gender, access to credit services, farm size, and quantity harvested significantly influence the decision of maize smallholder farmers on farming under a rented land system in a study area. 


\subsection{Policy Implications}

Although Tanzania has a vast number of relevant agricultural policies, programs, and strategies, the country has yet to bridge the gaps and reach targeted Sustainable Development Goals by 2030 particularly on achieving sustainable agriculture, end hunger, achieve food security, and improved nutrition. In response to this, it is pertinent that the country must increase its food security through investing in the linkage between land ownership systems, agricultural production, and productivity among smallholder farmers, particularly on the maize sector. Firstly, there is a need to create a conducive financing environment for maize smallholder farmers. This will enable the maize producers to have access to agricultural credits which could enhance them to increase maize agricultural production and productivity through renting good soil quality farm plots and accessing agricultural technologies. Furthermore, the paper recommends government and private sectors to increase their agricultural support towards maize producers through extension and education services which may help them to make proper decision on which type of land ownership system should be practiced in order to increase agricultural productivity and returns thereby bridging the gap of food security.

\section{Acknowledgement}

We thank the editorial board of the African Review for inviting this article and acknowledge the constructive comments from the anonymous reviewers on improving this paper. All remaining errors are ours.

\section{Disclosure Statement}

This study received no specific financial support and authors declare that there is no conflict of interest regarding the publication of this paper.

\section{References}

Antwi-Agyei, P., Dougill, A. J., \& Stringer, L. C. (2015). Impacts of land tenure arrangements on the adaptive capacity of marginalized groups: the case of Ghana's Ejura Sekyedumase and Bongo districts. Land Use Policy, 49, 203-212. 
Asaaga, F. A., \& Hirons, M. A. (2019). Windows of opportunity or windows of exclusion? Changing dynamics of tenurial relations in rural Ghana. Land Use Policy, 87, 104042.

Athey, S., \& Imbens, G. W. (2007). Discrete choice models with multiple unobserved choice characteristics. International Economic Review, 48(4), 1159-1192.

Bellemare, M. F. (2012). Insecure land rights and share tenancy: Evidence from Madagascar. Land Economics, 88(1), 155-180.

Bellemare, M. F. (2016). Metrics Monday: Simpson's Paradox, or Why "Determinants of ..." Papers Are Problematic. Retrieved from http://marcfbellemare.com/ wordpress/12082.

Collins, A. M., Grant, J. A., \& Ackah-Baidoo, P. (2019). The glocal dynamics of land reform in natural resource sectors: insights from Tanzania. Land use policy, 81, $889-896$.

Donkor, E., \& Owusu, V. (2014). Examining the socioeconomic determinants of rice farmer's choice of land tenure systems in the upper east region of Ghana.Journal of Agricultural Technology, $10(3), 505-515$.

Food and Agriculture Organization. (2018). The Gender Gap in Land Rights. Food and Agriculture Organization of the United Nations.

Gebreeyosus, M. A., Kelebe, H. E., \& Gebregziabher, T. N. (2020). Investments in farm land in Northern Ethiopia: a household-level analysis of the roles of poverty, tenure security, and conservation.Journal of Degraded and Mining Lands Management, $7(2), 2017-2028$.

Ghatak, M., \& Roy, S. (2007). Land reform and agricultural productivity in India: a review of the evidence. Oxford Review of Economic Policy, 23(2), 251-269.

Huang, J., Rozelle, S., Zhu, X., Zhao, S., \& Sheng, Y. (2020). Agricultural and rural development in China during the past four decades: an introduction. Australian Journal of Agricultural and Resource Economics, 59, 1-13.

Isinika, A. C., \& Mutabazi, K. (2010). Gender dimensions of land conflicts: Examples from Njombe and Maswa districts in Tanzania. In K. Havnevik, \& A. C. Isinika (Eds.), Tanzania in Transition: From Nyerere to Mkapa (pp. 131-158).

Kassie, M., Jaleta, M., Shiferaw, B., Mmbando, F., \& Mekuria, M. (2013). Adoption of interrelated sustainable agricultural practices in smallholder systems: evidence from rural Tanzania. Technological Forecasting and Social Change, 80, 525-540.

Kassie, M., Teklrwold, H., Jaleta, M., Marenya, P., \& Erenstein, O. (2015). Understanding the adoption of portfolio of sustainable intensification practices in Eastern and Southern Africa. Land Use Policy, 42, 400-411.

Keovilignavong, O., \& Suhardiman, D. (2020). Linking land tenure security with food security: Unpacking farm households' perceptions and strategies in the rural uplands of Laos. Land Use Policy, 9o, 10426o. 
Kinuthia, B. A. (2019). Off-farm participation, agricultural production and farmers' welfare in Tanzania and Uganda. Partnership for Economic Policy Working Paper 2019-01.

Lasway, A. J., Temba, R. G., \& Ruhinduka, D. R. (2020). Determinants of soil conservation technologies among small-scale farmers in Tanzania: evidence from National Panel Survey. African Journal of Economic Review, 8(1), 89-105.

Lasway, A. J., Selejio, O., \& Temba, G. R. (2021). Modeling multiple adoption decisions on agricultural technologies in Tanzania: a multinomial probit analysis. Tanzanian Economic Review, 10(2), 69-83.

Lawry, S. S. (2017). The impact of land property rights interventions on investment and agricultural productivity in developing countries: a systematic review. Journal of Development Effectiveness, 9(1), 61-81.

Massoi, L. W. (2019). Gender roles and practices in natural resource management among the Kilosa Maasai in Tanzania. Tanzania Journal of Development Studies, $17(1), 102-116$.

McFadden, D. L. (1984). Econometric analysis of qualitative response models. Handbook of Econometrics, 2, 1395-1457.

McFadden, D. L., Wright, R., Manski, C. F., \& Newey, W. K. (2007). Economics to Econometrics: Contributions in Honor of Daniel L. McFadden. Blackwell Publishing.

Mekasha, T. J., Ngasamiaku, W., Ruhinduka, R. D., \& Tarp, F. (2018). Land tenure security and internal migration in Tanzania. World Institute for Development Economic Research (UNU-WIDER), 158.

Melesse, T. M., \& Awel, Y. M. (2020). Land tenure, gender, and productivity in Ethiopia and Tanzania. In M. Konte, \& N. Tirivayi (Eds.), Women and Sustainable Human Development. Gender, Development and Social Change (pp. 89-108). Palgrave Macmillan.

Mullan, K., Grosjean, P., \& Kontoleon, A. (2011). Land tenure arrangements and ruralurban migration in China. World Development, 39(1), 123-133.

Mwesigye, F. G., Guloba, M., \& Barungi, M. (2020). Women's land rights and agricultural productivity in Uganda. In M. Konte, \& N. Tirivayi (Eds.), Women and Sustainable Human Development (pp. 71-88). Palgrave Macmillan.

National Bureau of Statistics. (2017). 2016-2017 Annual Agricultural Sample Survey (AASS). National Bureau of Statistics.

Ndiritu, S. W., \& Ruhinduka, R. D. (2019). Climate variability and post-harvest food loss abatement technologies: evidence from rural Tanzania. Studies in Agricultural Economics, 121, 30-40.

Nnkya, T. J. (1999). Land use planning practice under the public land ownership policy in Tanzania. Habitat International, 23(1), 135-155.

Pallotti, A., \& Tornimbeni, C. (2016). Rural development and the fight against poverty in Tanzania: a fifty-year perspective. In State, Land and Democracy in Southern Africa (pp. 39-6o). Farnham. 
Panichvejsunti, T., Kuwornu, J. K. M., Shivakoti, G. P., Grünbühel, C., \& Soni, P. (2018). Smallholder farmers' crop combinations under different land tenure systems in Thailand: The role of flood and government policy. Land Use Policy, 72, 129-137.

Pauw, K., \& Thurlow, J. (2011). Agricultural growth, poverty, and nutrition in Tanzania. Food policy, 36(6), 795-804.

Place, F., \& Otsuka, K. (2002). Land tenure systems and their impacts on agricultural investments and productivity in Uganda. The Journal of Development Studies, $38(6)$, $105^{-128 .}$

Ringo, J. (2018). Contribution of land tenure on enhancing subsistence farming in Kibaha District, Tanzania. International Journal of Food Nutrition and Safety, 9(1), 28-39.

Rwegasira, A. (2012). Land as a Human Right. Tanzania: A History of Land Law and Practice in Tanzania. Mkuki na Nyota Publisher Ltd.

Sanchez, P. (2015). En route to plentiful food production in Africa. Nature Plants, 1, 14014. doi:10.1038/nplants.2014.14.

Selejio, O. and Lasway, A. J. (2019). Economic analysis of the adoption of inorganic fertilisers and improved maize seeds in Tanzania. African Journal of Agricultural and Resource Economics Volume, 14(4), pp. 310-330.

Shivji, I. G. (1999a). Constructing a new rights regime: Promises, problems and prospects. Social and Legal Studies, 8, no. 2: 253-276.

Shivji, I. G. (1999b). The Land Acts 1999: A Cause for celebration or a celebration of a cause? Morogoro, Tanzania: Uds m Press.

Sipangule, K. (2017). Agribusinesses, Smallholder Tenure Security and Plot-level Investments: Evidence from Rural Tanzania. African Development Review, 29(S2), 179-197.

Sklenicka, P., Zouhar, J., Molnarova, K. J., Vlasak, J., Kottova, B., Petrzelka, P., Gebhart, M. and Walmsley, A. (2019). Trends of soil degradation: Does the socio-economic status of land owners and land users matter? Land Use Policy, p. 103992.

Tsikata, D. (2003). Securing women's interests within land tenure reforms: recent debates in Tanzania. Journal of Agrarian Change, 3(1-2), pp. 149-183.

Twyman, J., Useche, P., and Deere, C. D. (2015). Gendered perceptions of land ownership and agricultural decision-making in Ecuador: Who are the farm managers? Land Economics, 91(3): 479-500.

United Republic of Tanzania. (1995). The Land National Policy, 1995. Dar es Salaam: Government Printer.

United Republic of Tanzania. (1999a). The Land Act, 1999. Dar es Salaam: Government Printer.

United Republic of Tanzania. (1999b). The Village Land Act, 1999. Dar es Salaam: Government Printer.

United Republic of Tanzania. (2016a). National Land Policy (2016). Dar es Salaam: Government Printer. 
United Republic of Tanzania.(2016b).Agricultural Sector Development Programme Phase Two (ASDP II). Dodoma: The United Republic of Tanzania.

United States Agency for International Development. (2017). Tanzania - Land Tenure And Property Rights Profile. Dar es Salaam: United States Agency for International Development.

Wily, L. A. (2012). Looking back to see forward: The legal niceties of land theft in land rushes. Journal of Peasant Studies, 39, no. 3-4: 751-775.

Wooldridge, J. M. (2019). Introductory Econometrics: A Modern Approach, seventh edition. Cincinnati: OH: South-Western College Publishing. 